\title{
ČAS OBLIKOVANJA \\ NOVEGA SVETOVNEGA REDA
}

\author{
THE TIME OF THE FORMATION \\ OF A NEW WORLD ORDER
}

Povzetek Članek podaja analizo sprememb v strateškem varnostnem okolju od prve svetovne vojne do danes, ki zaznamuje začetek novega svetovnega reda, ter identificira ponavljajoče se vzorce in zakonitosti $\mathrm{v}$ celotnem obdobju, ki so se pojavili kot posledica prve svetovne vojne oziroma dogodkov takoj po njej, in njihovo preslikavo v današnji čas. Avtor trdi, da današnja varnostna vprašanja izvirajo predvsem iz odločitev, sprejetih na versajski mirovni konferenci, in iz dogodkov, ki so ji sledili. Druga svetovna vojna in hladna vojna sta večinoma logični posledici prve svetovne vojne. Ozemeljski spori in mnogi zamrznjeni konflikti v Srednji in Vzhodni Evropi so se ponovno razplamteli takoj po padcu Berlinskega zidu. To območje je ponovno polje geopolitične igre, v katero se vrača združena Nemčija, ki postaja dominantna politična sila v Evropi. S svetovno finančno krizo, ki je oslabila Evropsko unijo, strateško preusmeritvijo ZDA v vzhodno Azijo in na Pacifik ter z nedavno spremembo v varnostnem okolju zaradi krize v Ukrajini in odmika Rusije od Zahoda se nakazujejo težnje strateških premikov v varnostnem okolju. Ali bo to privedlo do novega svetovnega reda, pa je odvisno od naslednjih korakov strateških igralcev in od tega, kakšne so njihove pridobljene in predvsem ponotranjene izkušnje iz preteklega stoletja, ki bi pomagale preprečiti napake, narejene v tem obdobju.

Ključne besede

Novi svetovni red, prva svetovna vojna, geopolitika, mednarodne organizacije, nova Evropa, Nato, Rusija, Nemčija.

Abstract The article analyses the continuous change in the geostrategic security environment in Europe since the beginning of the World War I, which marked the beginning of a new world order. It walks us through the major strategic shifts in Europe during the $20^{\text {th }}$ century as a result of World War I in order to identify repetitive patterns and to see how they come into play today. The author argues that the $21^{\text {st }}$ century strategic issues are rooted in the decisions taken at the Versailles Peace Conference and that World War II and the Cold War were, in most parts, the logical consequences 
of the Great War. Territorial disputes and numerous frozen conflicts, mainly in the Central and Eastern Europe broke up immediately after the fall of the Berlin wall. This region, has been once and again the territory that sparks major geopolitical changes in Europe. Today, the very same region is again the point of departure of a new strategic game, with Germany at its core as the rising dominant power in Europe. The outbreak of the global financial crisis in 2008, which weakened the European Union together with the US pivoting to East Asia and Pacific, and the changed security environment in Europe due to the crisis in Ukraine and Russian geopolitical shift away from Europe, an emerging global strategic shift is shaping. The future will show how and if the strategic players will use the lessons of the past century in order to avoid making the same mistakes.

Key words New world order, World War I, geopolitics, international organizations, New Europe, NATO, Russia, Germany.

Uvod S prvo svetovno vojno je človeštvo pravzaprav vstopilo v 20. stoletje. Če francoska revolucija konec 18. stoletja in pomlad narodov leta 1848 pomenita formalni konec fevdalizma v Evropi, predstavlja prva svetovna vojna njegov geopolitični konec. Z njo se je začelo novo obdobje, ki ga živimo še danes. Dvajseto stoletje se je pravzaprav začelo s prvo svetovno vojno, saj so bili vsi poznejši dogodki v resnici posledica te vojne (povzeto po: MacMillan, 2003) in novega svetovnega reda, oblikovanega na pariški mirovni konferenci v Versaillesu leta 1919.

Bistveni dejavnik, ki je privedel do te velike vojne, je bila, kot ugotavlja tudi Simms, združitev Nemčije v drugi polovici 19. stoletja, ki je začela ogrožati ravnovesje sil, oblikovano po koncu napoleonovskih vojn (Simms, 2013). Ta dogodek je povzročil pretres na evropskem geopolitičnem zemljevidu, saj je dodal igri novega igralca, ki je hipoma zmagal v francosko-nemški vojni v letih 1870 in 1871 (povzeto po: Encyclopedia Britannica, 2014) ter postopoma začel ogrožati interese starih kolonialnih sil v Evropi in svetu. Ta zmaga in skokovit vzpon nemške industrijske proizvodnje, ki je potrebovala svetovno tržišče, sta povzročila strah predvsem v kolonialnih velesilah Franciji in Veliki Britaniji ter v Ruskem carstvu. Njihov odgovor na nemški vzpon je bil samodejen, rezultat pa je bilo oblikovanje vojaškega zavezništva antanta ( $f r$. Entente Cordiale). Na nasprotni strani sta se poleg Nemčije znašla še dva usihajoča večnacionalna imperija, habsburški in otomanski, ki sta navznoter doživljala implozijo, situacija strateškega vkopavanja pa jima je ustrezala predvsem za notranjepolitično konsolidacijo.

Razvoj dogodkov v prejšnjih sto letih avtor označuje kot nenehno geostrateško igro ničelne vsote. Ta se uporablja v teoriji iger, nanaša pa se na igro, v kateri en igralec zmaga, drugi pa izgubi, skupni rezultat igre pa je vedno nič (povzeto po: Ferguson, 2014). Nekako se zdi, da se danes svetovna igra ponovno vrača na izhodiščne položaje pred ubojem avstro-ogrskega prestolonaslednika Franca Ferdinanda v Sarajevu junija 1914, ki sicer ni bil vzrok za vojno, temveč njen sprožilec. Takrat, 
podobno kot danes, je potekal boj za nadzor nad Srednjo in Vzhodno Evropo (povzeto po: Mackinder, 1919). Slednja po Mackinderju ${ }^{1}$ že spada v tako imenovano strateško osrčje (angl. Heartland) (povzeto po: Mackinder, 1919). Natanko stoletje pozneje, leta 2014, je svet prvič po koncu hladne vojne in Natovem bombardiranju Zvezne republike Jugoslavije spomladi leta 1999 ponovno postavljen pred mogoče konflikte velikih razsežnosti v Vzhodni Evropi. Vprašanje je, ali je dovolj ponotranjil pridobljene izkušnje iz 20. stoletja in bo tako zmožen premostiti skušnjave sodobnih varnostnih izzivov.

Namen tega članka je prispevati k širši razpravi o posledicah velike vojne na razvoj dogodkov v 20. stoletju ter odpreti vprašanje, kje smo po sto letih. V okviru tega sicer širokega vprašanja se bomo osredotočili predvsem na dve vprašanji:

- katere so glavne varnostno-politične spremembe, ki jih je prinesla prva svetovna vojna, s čimer se je vzpostavil, kot je to poimenoval takratni predsednik ZDA Wilson ${ }^{2}$, nov svetovni red;

- kako zgodovinsko izkušnjo iz preteklih sto let preslikati v današnjo svetovno stvarnost in ali se svetovni red danes oblikuje na novo.

Izhajali bomo iz teh parametrov: Evropa in svet sta se s prvo svetovno vojno korenito spremenila. Vzroke za drugo svetovno vojno je mogoče iskati v rezultatih in posledicah prve svetovne vojne in sklepov, sprejetih na versajski mirovni konferenci v Parizu. Ustanovitev Društva narodov kot predhodnika večine današnjih mednarodnih organizacij, utemeljenih na načelih OZN, je temelj današnje evropske (in svetovne) varnostno-politične ureditve. Danes je mogoče iskati primerjave z dogodki, ki so se pojavili po letu 1918 in se obdobno ponavljajo. Dogodki, ki se dogajajo od svetovne finančne krize leta 2008, nakazujejo težnje po strateških spremembah. To lahko posledično vodi do oblikovanja novega svetovnega reda.

\section{POSLEDICE PRVE SVETOVNE VOJNE}

\subsection{Kaj se je spremenilo s prvo svetovno vojno}

Poleg geopolitične spremembe v Evropi avtor prispevka med tri bistvene dejavnike, ki so usmerjali razvoj 20. stoletja, prišteva tudi ideološkega. Tretji dejavnik je vstop ZDA v vojno leta 1917 in posledično njihova vojaška in politična zavzetost na stari celini kljub tako imenovani Monrojevi doktrini, ki poudarja pomen nevmešavanja evropskih sil v zadeve Latinske Amerike, v zameno pa daje zavezo o nevmešavanju ZDA v evropske (The Monroe doctrine, 1823).

\footnotetext{
Sir Halford John Mackinder, eden utemeljiteljev moderne geopolitične misli, avtor teorije o osrčju (Heartland) Sodeloval je na mirovni konferenci v Versaillesu leta 1919 in istega leta izdal knjigo z naslovom Democratic Ideals and Reality. Njegova zamisel o vzpostavitvi tamponskih držav med Nemčijo in Rusijo je bila po konferenci uresničena. Leta 1924 je na podlagi izkušenj iz prve svetovne vojne objavil teorijo o atlantski skupnosti, ki se je materializirala po koncu druge svetovne vojne v vojaški različici, v Natu.

2 Wodrow Wilson je bil 28. predsednik ZDA. Predsedoval jim je v letih od 1913 do 1921. Državo je popeljal v prvo svetovno vojno na strani zmagovite antante. Bil je ena najpomembnejših osebnosti na versajski mirovni konferenci leta 1919 in med drugim velik zagovornik pravice do samoodločbe narodov ter eden očetov Društva narodov, za katero je menil, da je temelj novega svetovnega reda.
} 
Z nastankom novih držav na pogoriščih starih imperijev je v geopolitičnem smislu nastal prazen prostor, ki je zahteval novo ravnotežje sil, predvsem v Srednji in Vzhodni Evropi. Ta del sveta je s koncem prve svetovne vojne postal območje za širjenje interesov in to ostal še vse 20. stoletje. Ključna država med obema vojnama na tem območju je bila za Friedmana Poljska, ki je z Romunijo, s katero je imela med obema vojnama ozemeljski stik, predstavljala zid med Baltskim in Črnim morjem, med takrat boljševistično Sovjetsko zvezo in zahodnim svetom (povzeto po: Friedman, 2014). Obe državi sta bili zaveznici Francije in Velike Britanije.

Z drugo svetovno vojno se je ta klasična geopolitična konstelacija spremenila in dobila primarno ideološko razsežnost. Nastavki zanjo so začeli nastajati že sredi prve svetovne vojne, z oktobrsko revolucijo leta 1917 v takratni carski Rusiji. Cesarska Nemčija si je zelo prizadevala zanetiti revolucijo, ki bi Rusijo izločila iz vojne, da bi vse svoje sil lahko premestila na zahodno bojišče in odločila vojno sebi v prid. To se je sicer zgodilo, saj je Rusija po tem, ko so 7. novembra 1917 boljšseviki prevzeli oblast, sklenila premirje s centralnimi silami in 3. marca $1918 \mathrm{v}$ Brest-Litovsku podpisala mir (The Treaty of Brest-Litovsk, 1918).

Vstop ZDA v vojno na strani antante leta 1917 je prevesil zmago na stran antantnih sil. Takrat se je prvič zgodilo, da so ZDA vojaško posredovale v Evropi. Prav tako so kot ena izmed zmagovitih držav dejavno oblikovale novo povojno geografsko podobo Evrope. Ne glede na to, da so se ZDA po koncu Wilsonovega mandata umaknile iz Evrope, ostaja dejstvo, da so se v drugi svetovni vojni ponovno pridružile Veliki Britaniji in Franciji proti centralnim silam, ki so jih sestavljale Nemčija, Italija in Japonska, ki so podpisale trojni pakt (The Three-Power Pact, 1940). Od takrat so ZDA vojaško in politično prisotne v Evropi.

Države udeleženke pariške mirovne konference so junija 1919 podpisale listino, s katero so se obvezale, da ustanovijo Društvo narodov. To je bila mednarodna organizacija, ki je nastala $\mathrm{v}$ upanju, da bo konflikte preprečevala s spodbujanjem politike razoroževanja, odprte diplomacije, mednarodnega sodelovanja in $\mathrm{s}$ sankcijami, ki bi vojno naredile neatraktivno (The Versailles Treaty, Part I., 1919). Društvo narodov je nehalo delovati po koncu druge svetovne vojne, ko so bili ustanovljeni Združeni narodi, čeprav je bilo pravnoformalno vanje vključeno kot njihov predhodnik (UN, 1945).

\subsection{Travma druge svetovne vojne}

Drugo svetovno vojno je po avtorju prispevka mogoče gledati v luči rezultata in posledic prve. Vojne reparacije, izčrpana industrija, politična nestabilnost in izguba ozemelj so bile za Nemčijo travmatična izkušnja. Po drugi strani je takratna Kraljevina Italija pričakovala višjo nagrado za vstop v vojno na strani antante ${ }^{3}$. Poleg tega se je pojavila še Sovjetska zveza, nov ideološki element, ki je po končani državljanski

3 Posledica je t. i. marš na Rim 28. oktobra 1922 in prihod fašistov (in Benita Mussolinija) na oblast. 
vojni v začetku dvajsetih let grozila z izvozom revolucije na zahod ${ }^{4}$ Svetovna gospodarska kriza leta 1929 je takšne nestabilne razmere le še poslabšala in januarja 1933 v Nemčiji povzročila prihod nacistov na oblast, španska državljanska vojna pa se je tik pred začetkom druge svetovne vojne dogajala na območju, na katerem sta se prvič spopadli dve nasprotujoči si ideologiji, nacizem in komunizem (povzeto po: Simms, 2013).

Evropa je iz druge svetovne vojne izšla kolektivno zelo oslabljena. Centralne sile so bile poražene, Francija kot zmagovalka prve svetovne vojne je vojno leta 1940 sicer vojaško zgubila, a se je vanjo vrnila kot zmagovalka, predvsem zaradi pomoči zaveznikov. Velika Britanija se je obdržala predvsem zaradi svoje geografske lege, vojna pa se je obrnila v njeno korist po vstopu ZDA v vojno. Kot pravi Simms, je Evropa, vključno s starimi kolonialnimi silami, predvsem pa Nemčija, po koncu druge svetovne vojne leta 1945 in s hkratnim začetkom hladne vojne v resnici postala potencialno vojskovališče dveh novih velesil, ZDA in Sovjetske zveze, ki sta si razdelili interesna območja na stari celini. To je trajalo do konca hladne vojne leta 1990, ki se je končala tam, kjer se je tudi začela, v Nemčiji (povzeto po: Simms, 2013). Evropske države so po dveh svetovnih vojnah prvič izgubile vodilno vlogo v svetovni politiki in prišle pod območje vpliva tretjih (zunajevropskih) sil. Prišel je čas za gradnjo novih, nadnacionalnih temeljev, ki bi to izgubo nadomestili.

\subsection{Mednarodne organizacije kot posebnost 20. stoletja}

Ustanavljanje mednarodnih organizacij po letu 1945 je nova razsežnost v političnem razvoju človeštva (še posebno Evrope). Po izkušnjah dveh svetovnih vojn in soglasju zmagovalcev v drugi svetovni vojni, da je treba ustanoviti svetovno mednarodno organizacijo, ki bo vključevala vse svetovne države in bo, drugače kot predvojno Društvo narodov, vplivala na države, ki ne bodo spoštovale mednarodnega reda, so bili 24. oktobra 1945 ustanovljeni Združeni narodi. Od ustanovitve so skupaj s specializiranimi agencijami in drugimi povezanimi organizacijami temelj mednarodnih miru in varnosti (UN, 2014).

Ustanovna listina Združenih narodov, posebno njen 51. člen, je služila kot pravna podlaga za ustanovitev regionalnih varnostnih organizacij (UN Charter, 1945), kot sta Organizacija Severnoatlantske pogodbe (v nadaljevanju Nato), ustanovljena leta 1949 (Nato, 1949), in Varšavski sporazum o prijateljstvu, sodelovanju in vzajemni pomoči (v nadaljevanju Varšavski pakt), ustanovljen leta 1955 ter razpuščen leta 1991. Varnostni organizaciji sta odražali takratno hladno vojno, ravnotežje sil, temelječe na dveh velesilah, ZDA in Sovjetski zvezi (Nato, 2014). Bistveno je to, da sta obe velesili postavili pravila igre in igro vodili tudi znotraj Združenih narodov.

Zahodnoevropske države so v obdobju po drugi svetovni vojni pospešeno izgubljale vpliv, ki so ga imele pred njo. Ta proces se je začel že po prvi svetovni vojni, v obdobju hladne vojne pa je bil v boju za svetovna vplivna območja med dvema velesilama

4 Revolucionarno vrenje se je na koncu vojne najradikalneje pojavilo v Nemčiji, Avstriji in na Madžarskem. 
še hitrejši. Evropske države so s poglobljenim gospodarskim sodelovanjem želele preseči nekdanje politične, gospodarske in vojaške napetosti, zato so ustanovile tri nadnacionalne organizacije ${ }^{5}$, ki so se leta 1967 združile v Evropsko gospodarsko skupnost (EU, 1967). Ta skupnost je bila predhodnica današnje Evropske unije, ki je leta 1993 nastala na podlagi sporazuma iz Maastrichta (EU, 1992).

Za Evropo je pomembna še Organizacija za varnost in sodelovanje v Evropi (OVSE), ki je prav tako nastala po načelih Ustanovne listine OZN. Leta 1975 je njena predhodnica Konferenca o varnosti in sodelovanju v Evropi sprejela Helsinško sklepno listino, v kateri so se države med drugim zavezale, da bodo spoštovale nedotakljivost mednarodno priznanih meja (pogosto oblikovanih na rezultatih versajske mirovne konference in po drugi svetovni vojni), suverenost držav podpisnic, ne bodo grozile drugim članicam, uporabljale sile proti njim ali se vmešavale v notranje zadeve drugih držav, spoštovale bodo pravico do samoodločbe narodov ter $\mathrm{v}$ dobri veri izpolnjevale obveznosti, ki izhajajo iz mednarodnega prava (OSCE, 2013).

\section{OBDOBJE GEOSTRATEŠKE TRANZICIJE}

\subsection{Konec hladne vojne in začetek tranzicijskega obdobja}

Hladna vojna se je končala s padcem Berlinskega zidu jeseni 1989, združitvijo obeh Nemčij (vzhodne in zahodne) leta 1990 ter razpustitvijo Varšavskega pakta julija 1991 in Sovjetske zveze decembra istega leta (Nato, 2014). Sovjetska zveza je od konca prve svetovne vojne poosebljala enega svetovnih centrov politične in predvsem ideološke moči, po koncu druge svetovne vojne pa tudi eno izmed dveh vojaških velesil. S padcem Berlinskega zidu se je to spremenilo.

Hkrati s propadom komunizma, ki je bil uveden v državah Srednje Evrope po drugi svetovni vojni, sta razpadli tudi večnacionalni državi, ki sta nastali po prvi svetovni vojni (Jugoslavija 1991 in Češkoslovaška 1993). Geostrateški prostor se je v tem obdobju spremenil. Na območju Srednje in Vzhodne Evrope je nastalo več novih majhnih držav, ki so začele definirati svoj strateški prostor v Evropi. Rešitev so našle v pridružitvi h kontinentalni ekonomsko-politični skupnosti - Evropski uniji in čezatlantski varnostni skupnosti - Natu. Kot ugotavlja Simms, sta s perspektivo o članstvu v obeh organizacijah ta dva projekta uspela združiti države vzhodnega bloka, tako ekonomsko kot politično in varnostno (povzeto po: Simms, 2013). Avtor meni, da se je s tem zmanjšala možnost morebitnih konfliktov v Srednji in Vzhodni Evropi, hkrati pa sta se obe organizaciji razširili v zahodni del strateškega jedra (po Mackinderju).

Po razpadu Sovjetske zveze leta 1991 se je prehodno obdobje začelo tudi v Ruski federaciji, zaznamuje ga predsedovanje Borisa Jelcina. Dejstvo je, da se je v

Skupnost za premog in jeklo leta 1952, Evropska gospodarska skupnost in Evropska skupnost za atomsko energijo (Euratom), obe 1958. 
devetdesetih letih prejšnjega stoletja Rusija začela odpirati proti zahodu. Hkrati je začela osrednja moč Moskve slabeti na račun federalnih enot in regij. Rusija tistega obdobja je doživljala več političnih konfliktov, ki so dosegli vrhunec oktobra 1993, ko je Jelcin z vojsko napadel parlament (Dumo), kar se je zgodilo prvič po letu 1917. Po zasedbi parlamenta je bila v kratkem obdobju sprejeta nova ustava, ki je predsedniku dajala široka pooblastila in uvedla predsedniški sistem. Simms ugotavlja, da je Rusija tudi vojaško doživljala neuspehe, še posebno ob porazu v prvi čečenski vojni leta 1996 (povzeto po: Simms, 2013). Obdobje tranzicije se je v Rusiji v resnici končalo leta 2000 z izvolitvijo Vladimirja Putina, kar avtor razloži v nadaljevanju.

\subsection{Vstop v 21. stoletje in nastanek nove Evrope}

Vstop v 21. stoletje so po avtorjevem mnenju zaznamovali teroristični napadi v ZDA septembra 2001, kot posledica tega pa tudi vojni v Afganistanu 2001 in Iraku 2003. Dejstvo je, da so ZDA vse prvo desetletje pozornost v zunanji in obrambni politiki namenjale predvsem povračilnim ukrepom za teroristične napade v New Yorku in Washingtonu. Za posredovanje v Afganistanu v začetku oktobra 2001 sicer niso imele soglasja Varnostnega sveta OZN, a je bila intervencija pod vodstvom $Z_{D A}^{6}$ širše razumljena kot legitimna oblika samoobrambe, ki je skladna z Ustanovno listino OZN. Boji so bili končani sredi decembra, nekaj dni za tem pa je Varnostni svet OZN odobril uvedbo misije za podporo prehodni afganistanski vladi za pomoč pri ohranjanju miru (Isaf) ${ }^{7}$. Isaf je po napadu na Irak avgusta 2003 prešel pod poveljstvo Nata (Nato, 2014).

Drugače pa je bilo s posredovanjem ZDA v Iraku leta 2003. ZDA so v Varnostnem svetu dosegle sprejetje Resolucije št. 1441, ki je režimu Sadama Huseina dala zadnjo možnost, da izpolni mednarodne obveznosti za nadzor oborožitve (UN, 2002) ${ }^{8}$. ZDA so dokazovale, da Irak tega ni storil in da ima na voljo orožje za množično uničevanje (kar se je izkazalo za neresnično), zato so spomladi 2003 vojaško posredovale ${ }^{9}$ skupaj s tako imenovano koalicijo voljnih ${ }^{10}$.

Vojaškemu posredovanju v Iraku sta nasprotovali najpomembnejši članici EU Francija in Nemčija (povzeto po: The Guardian, 2003). Prvič po drugi svetovni vojni se je zgodilo, da je Nemčija odkrito nasprotovala zunanjepolitični odločitvi ZDA. Tedanji sekretar za obrambo Rumsfeld je zavezništvo Francije in Nemčije poimenoval stara Evropa, ki se od nove Evrope razlikuje po tem, da ne podpira

${ }^{6}$ ZDA so se pridružile še Velika Britanija, Avstralija in Severno zavezništvo (kot opozicijske sile, ki so se bojevale proti Talibskemu režimu v Afganistanu).

International Security Assistance Force (ISAF).

8 Resolucija VS OZN 1441 med drugim prepoznava grožnjo mednarodnemu miru in varnosti, ki jo predstavlja Irak zaradi neizpolnjevanja obveznosti, ki izhajajo iz predhodnih resolucij (ki se nanašajo na prvo vojno v Iraku $v$ začetku 90. let), proliferacije orožja za množično uničevanje in raket dolgega dosega.

9 Povod za napad je bila ocena obveščevalnih služb, da ima Irak orožje za množično uničevanje. Vojni so nasprotovale Francija, Nemčija in Rusija ter večina arabskih držav.

${ }^{10}$ Koalicijo voljnih je sestavljalo 48 držav, od katerih so štiri (ZDA, Združeno kraljestvo, Avstralija in Poljska) prispevale svoje vojaške enote. 
odločitve, ki je ključna za ZDA (povzeto po: Baker, 2003). Z novo Evropo je Rumsfeld označil države Srednje in Vzhodne Evrope, od katerih so Poljska, Češka in Madžarska vstopile v Nato leta 1999, sedem preostalih (Estonija, Latvija, Litva, Slovaška, Slovenija, Romunija in Bolgarija) pa jim je sledilo leta 2004. Države, ki so si prizadevale za članstvo v Natu ${ }^{11}$, so v začetku februarja 2003 podpisale dokument, ki ga označujemo kot vilniuško izjavo, v katerem so podprle namero ZDA po vojaškem posegu v Iraku (povzeto po: Gherghisan, 2003).

Rumsfeldova nova Evropa se je pojavila kot nov geostrateški pojem, ki od tega trenutka, formalno pa z drugo razširitvijo Nata in vstopom teh držav v EU spomladi 2004, vključuje nekdanje ozemlje Varšavskega pakta ${ }^{12}$, s katerim se je Evropa varnostno in politično zaokrožila ter približala ruskim mejam in kamor se je preselilo evropsko geopolitično težišče (povzeto po: Baker, 2003).

\subsection{Svetovna finančna kriza in njene posledice}

Z bankrotom bančnega giganta iz ZDA Lehman Brothers septembra 2008 je bilo dokončno jasno, da se je svet znašel v globalni finančni krizi. Kriza, ki se je nakazala že leta 2007 s krizo nepremičninskega trga, je nastala kot posledica dolgoletnih finančnih špekulacij na svetovnih finančnih trgih. V ZDA je sprožila recesijo in se kmalu razširila po vsem svetu ter se v Evropi spremenila v krizo evra (povzeto po: The Economist, 2013). To je najgloblja finančna kriza po svetovni depresiji, ki se je začela deset let po koncu prve svetovne vojne, leta 1929, in trajala skoraj do druge svetovne vojne. Evropa in svet sta bila nanjo nepripravljena. Prva žrtev krize v Evropi je bila Grčija, ki se je morala spoprijeti s kombinacijo strukturnih pomanjkljivosti v gospodarstvu ter z visokimi proračunskimi primanjkljaji (povzeto po: Nelson, Belkin, Mix, 2011). Podobne težave so imele še Portugalska, Irska, Italija in Španija. Težave z odplačevanjem obveznosti so vplivale tudi na evro, ki je postal zelo nestabilen (povzeto po: The Economist, 2013).

Odgovori na krizo evra se kažejo v manjšanju javnih izdatkov v večini držav članic. Posledično to pomeni manj javnih sredstev za socialo, zdravstveno zavarovanje, kulturo in druge javne službe, ki so po drugi svetovni vojni, predvsem v Zahodni Evropi, predstavljale model za države blagostanja. To jim je po prepričanju avtorja dajalo politično privlačnost, kar je po eni strani prispevalo h krhanju režimov $\mathrm{v}$ vzhodnem bloku in k želji po pridružitvi držav Srednje in Vzhodne Evrope temu modelu zahoda, po drugi pa je prispevalo k povečanju imigracije iz neevropskih držav - nekdanjih kolonij, predvsem iz Severne Afrike in z Bližnjega vzhoda.

Prav tako tudi obrambnim izdatkom pri manjšanju proračunov ni bilo prizaneseno (Nato, 2014). Države so se odzvale različno. V zahodnem delu Evrope so se praviloma odločale za zmanjševanje obrambnih sil in določanje, katere zmogljivosti imajo prednost. Zanimiv je podpis pogodbe o strateškem partnerstvu, ki sta

\footnotetext{
"I To so bile: Albanija, Bolgarija, Hrvaška, Estonija, Latvija, Litva, Makedonija, Romunija, Slovaška in Slovenija.

${ }^{12}$ Razen Slovenije ter Hrvaške in Albanije. Slednji sta v Nato vstopili leta 2009.
} 
jo podpisali Francija in Velika Britanija leta 2010, v kateri sta se sporazumeli o tesnejšem obrambnem sodelovanju. Posebna pozornost v pogodbi je namenjena testiranju novih jedrskih zmogljivosti, vzdrževanju in servisiranju sedanjih jedrskih zmogljivosti obeh držav ter souporabi letalonosilk (UK-France Treaty, 2010). Podpis pogodbe je bil v Veliki Britaniji predstavljen kot ukrep za učinkovito zmanjšanje stroškov v obrambnem sistemu, vendar obenem daje vtis strateškega približevanja obeh držav.

Med pomembnimi posledicami finančne krize v Evropski uniji sta v notranjepolitičnem dogajanju naraščanje evroskepticizma in pojav skrajnih (protievropskih in protipriseljenskih) političnih strank, tako na volitvah v evropski parlament (2014 V primerjavi z volitvami iz leta 2009) kot na nacionalnih volitvah (povzeto po: The Economist, 2014). Še posebno povzročajo skrbi težnje v največjih državah, kot sta Francija (Narodna fronta voditeljice Marine Le Pen) in Velika Britanija (stranka protievropsko naravnanega politika Nigela Faragea, UKIP), v katerih se je evroskepticizem, podžgan s finančno krizo, odrazil v obljubi britanskega predsednika vlade Davida Camerona, da leta 2017 razpiše referendum o izstopu Velike Britanije iz Evropske unije (povzeto po: The Economist, 2013).

\section{GEOSTRATEŠKI PREMIKI}

\subsection{Nova Evropa kot mejno ozemlje za Zahodno Evropo}

V zadnjem času, posebno pa od leta 2014, se prostor nove Evrope ponovno pojavlja kot območje nove geopolitične igre, tokrat med ZDA in Nemčijo na eni strani in vojaško revitalizirano Rusijo ${ }^{13}$ na drugi. Rusija je po ocenah Inštituta za strateške študije iz Londona $\mathrm{v}$ letih od 2008 do 2013 povečala obrambni proračun za 31 odstotkov (povzeto po: The Japan Times, 2014). Na pojav nove geopolitične igre v svojih razmišljanjih namiguje tudi geostrateg George Friedman iz Stratforja. Po Friedmanu (Friedman, 2014) se je s pojavom finančne krize v Evropi spremenil predvsem položaj Nemčije, ki zaradi gospodarske moči ponovno preračunava svojo prihodnjo vlogo v Evropi. Še posebno zaradi strateške preusmeritve ZDA v vzhodno Azijo (US Strategic Guidance, 2012) ${ }^{14}$, s čimer se je manevrski prostor za igro v Evropi razširil. Vanjo je poleg Nemčije odločneje vstopila tudi Rusija. Tradicionalno sta ti dve državi (in habsburški imperij do prve svetovne vojne) odločali o usodi ozemelj in narodov Srednje in Vzhodne Evrope. To pa je območje ki ga je Ramsfeld pred desetletjem poimenoval nova Evropa, za Friedmana je to mejno ozemlje (borderlands), za Mackinderja pa zahodni del strateškega osrčja.

To mejno ozemlje je dobilo pomembno razsežnost po prvi svetovni vojni. Po boljševistični revoluciji v Rusiji leta 1917 in kapitulaciji Nemčije novembra 1918

\footnotetext{
${ }^{13}$ Po ocenah Inštituta za strateške študije iz Londona je Rusija od leta 2008 do 2013 povečala obrambni proračun za $31 \%$.

${ }^{14}$ Nova obrambna strategija ZDA, sprejeta januarja 2012, predvideva prednostno strateško pozornost vzhodni Aziji in Pacifiku.
} 
je Poljska ponovno (po 1795) postala neodvisna država ${ }^{15}$. Friedman poudarja, da je njen prvi voditelj in vojskovodja general Pilsudski poskušal obuditi zamisel nekdanje poljsko-litovske države (Država obeh narodov), ki je nastala sredi 16. stoletja. Obsegala je območje med dvema morjema, Baltskim in Črnim, in je bila nekakšen zid med vzhodom in zahodom, kar je bilo pojmovano kot koncept medmorja ali po latinsko intermarum. Cilj je bil preprečiti vdor sovjetske Rusije v Evropo ter onemogočiti njen stik z Nemčijo (povzeto po: Friedmann, 2014). To se mu ni posrečilo, saj so se preostale države bale izgube nedvisnosti (npr. Litva in takratna Ukrajina), po drugi strani pa je Rdeča armada zasedla Belorusijo in Ukrajino ter ju vključila v novo sovjetsko državo (od 1922 Sovjetska zveza). Poljska se je rešila z vojaško zmago pred Varšavo leta 1920, s čimer se je marca 1921 uradno končala sovjetsko-poljska vojna, začeta februarja 1919.

Posebno poglavje sovjetsko-poljske vojne je bila Ukrajina, ki je bila v načrtih Pilsudskega mišljena kot bistveni element medmorja (Friedman, 2014). Po drugi strani je bil Leninov cilj zasesti vsa ozemlja, ki jih je propadla carska Rusija izgubila z mirom, podpisanim v Brest-Litovsku ${ }^{16}$, vključno s Poljsko. To bi dalo boljševikom dobro izhodiščno točko za svetovno revolucijo, ki je imela široko podporo $\mathrm{v}$ povojnem revolucionarnem vrenju v Nemčiji, Avstriji in na Madžarskem.

Od konca prve svetovne vojne je bilo območje srednje Evrope med Baltikom in Črnim morjem, kot to poimenuje avtor, »lakmusov papir« geostrateških sprememb v Evropi. Od Pilsudskega, nemške okupacije Češkoslovaške leta 1938, napada na Poljsko leta 1939 ter obdobja sovjetske okupacije med hladno vojno pa vse do zloma komunizma, ki se je začel s Solidarnostjo na Poljskem in končal z vključitvijo teh držav $\mathrm{v}$ Evropsko unijo in Nato pred dobrim desetletjem, je to območje sovjetom predstavljalo morebitno bojno polje ter strateško globino. Vseh zadnjih sto let so bile države pod vplivom geostrateških iger velikih igralcev, med katere so bile umeščene. Friedmann je prepričan, da bi bila ponovna obuditev projekta intermarum, ki bi vključeval Poljsko, Slovaško, Madžarsko, Romunijo in pogojno tudi Bolgarijo, ključen geostrateški dejavnik v Evropi, ki bi preprečil ruski vpliv, blokiral stik Nemčije in Rusije ter omejil turški vpliv, ki se po sto letih ponovno krepi v Jugovzhodni Evropi (povzeto po: Friedmann, 2014). Fridmanovo razmišljanje je v delu, ki obravnava Nemčijo in Rusijo, podobno Mackinderjevim zamislim o ureditvi Vzhodne Evrope iz leta 1919 (povzeto po: Mackinder, 1919 in Friedman, 2014).

\subsection{Odnosi med Natom in Rusijo}

V prvem desetletju 21. stoletja se je zdelo, da sta Zahod in Rusija našla skupni jezik o političnem in poslovnem sodelovanju, kar je zagotavljalo stabilnost v Evropi. Še posebno po 11. septembru 2001, ko sta obe državi prepoznali skupno nevarnost $\mathrm{v}$ islamskem terorizmu, in sicer ZDA v Al-Kaidi in z njo povezanih skrajnih islamskih

\footnotetext{
${ }_{15}$ Nemčija se je v začetku prve svetovne vojne in po prodoru centralnih sil v Rusijo odločila oblikovati več držav, med njimi tudi Poljsko, ki bi bile tesno vezane na Nemčijo in bi služile kot vmesno ozemlje med Nemčijo in Rusijo. Ta projekt so imenovali Mittelevropa.

${ }^{16}$ Podpisana marca 1918.
} 
skupinah, Rusi pa v teroristični nevarnosti, ki je izhajala iz posledic dveh vojn $\mathrm{v}$ Čečeniji. Putin in njegov naslednik na predsedniškem položaju Dimitrij Medvedjev sta državo v tem obdobju politično notranje konsolidirala, in to predvsem na račun ugodnih cen pri izvozu nafte in plina, kar je nekajkrat povečalo njen bruto družbeni proizvod $^{17}$. Sodelovanje z Natom se je po letu 1997, ko je bil podpisan Ustanovitveni akt med Natom in Rusijo, poglobilo in od leta 2002 preraslo v strateško partnerstvo (Nato, 2002). Bistveni pomen tega partnerstva je v vzpostavitvi skupne osnove $\mathrm{v}$ obliki Sveta Nato-Rusija, znotraj katere se Nato in Rusija pogovarjata na enakopravni ravni in poglabljata medsebojne odnose ter gradita zaupanje (Nato, 2002).

Na vrhu Nata v Bukarešti aprila 2008 so vodje držav in vlad članic Nata sklenili, da bosta tudi Ukrajina in Gruzija postali članici Nata ${ }^{18}$ (Nato, 2008). Določnost tega dela besedila deklaracije je bilo svojevrstno presenečenje, saj je bilo precedens tako V načinu pošiljanja sporočil mednarodni skupnosti, vključno z Rusijo, kot tudi v diplomatski praksi, ki ji je obljubljanje nekega dejanja vnaprej tuje. Avtor meni, da je bil to po vstopu držav Srednje in Vzhodne Evrope (predvsem Baltskih držav) v Nato eden ključnih trenutkov, ki je v Rusiji obudil tradicionalno nezaupanje do Zahoda (v glavnem ZDA) in Nata kot njegove vojaške platforme.

Odgovor je prišel kmalu. Vrhu Nata v Bukarešti sta še istega leta sledili vojna v Gruziji in začasna zamrznitev Sveta Nato-Rusija. Februarja 2010 je Rusija objavila svojo novo vojaško doktrino, v kateri sta bila nadaljnja širitev Nata na ruske meje in nameščanje njegove vojaške infrastrukture v novih članicah v bližini ruskih meja med drugimi ${ }^{19}$ grožnjami opredeljena kot primarna zunanja grožnja nacionalni varnosti (The Military Doctrine, 2010).

Po začetku krize v Ukrajini so ZDA jeseni 2014 obvestile Severnoatlantski svet o tem, da Rusija krši obveznosti iz pogodbe o jedrskih silah srednjega dometa (INF) ${ }^{20}$, ki zavezuje ZDA in Rusijo, da nimata, ne proizvajata in ne testirata raket dometa med 500 in $5500 \mathrm{~km}$ oziroma nimata in ne proizvajata lansirnih ramp za takšne rakete (Nato, 2014). Cilj te pogodbe je bil zmanjšati grožnje varnosti in stabilnosti v Evropi, še posebno grožnje hitrega napada na tarče, ki imajo strateško vrednost (The INF Treaty, 1987 in Nato, 2014). Ta pogodba je eden izmed temeljev evroatlantske varnosti in stabilnosti. ZDA so vztrajale, da imajo dokaze o tem, da Rusija teh zahtev ne izpolnjuje, zato so jo začele pozivati, da začne izpolnjevati obveznosti iz te pogodbe, saj sicer ruši strateško ravnotežje v Evropi (Nato, 2014).

\footnotetext{
${ }^{17}$ V 90. letih je Rusija gospodarsko stagnirala. Leta 1998 jo je prizadela globoka gospodarska kriza. Po statističnih podatkih, s katerimi razpolaga Trading Economics, je BDP Rusije leta 1990 znašal 516 milijard USD, leta 2000, ko je dosegel dno, pa le še 196 milijard. Deset let pozneje se je dvignil na 1222 milijard, leta 2014 pa je znašal 2096 milijard.

${ }^{18}$ Ta sklep je bil objavljen v uradni deklaraciji na vrhu Nata v Bukarešti 3. aprila 2008.

${ }_{19}$ Druge grožnje vključujejo še ogrožanje strateške stabilnosti, nameščanje tujih vojaških enot v sosednjih drzavah, razvoj balistične raketne obrambe, ki ruši strateško ravnovesje, itn.

${ }^{20}$ INF - Intermediate-Range Nuclear Forces Treaty; pogodba med ZDA in takratno Sovjetsko zvezo je začela veljati leta 1988. Po razpadu Sovjetske zveze je Rusija postala njena pravna naslednica in je prevzela tudi vse mednarodnopravne obveznosti.
} 
To pa ni bilo prvič po hladni vojni, da Rusija ni izpolnjevala pogodbenih obveznosti, ki zagotavljajo strateški mir v Evropi. Leta 2007 je namreč izstopila iz Pogodbe o konvencionalnih silah v Evropi ${ }^{21}$ (OSCE, 2007) in s tem nakazala, da ni zadovoljna $\mathrm{z}$ mednarodno varnostno ureditvijo.

\subsection{Ukrajinska kriza 2014}

Krizo v Ukrajini leta 2014 je treba gledati v okviru širše geostrateške igre, ki se je začela nakazovati že leta 2004 z zmago prozahodnega kandidata za predsednika Ukrajine Viktorja Juščenka. Do leta 2010 je bila v Ukrajini na oblasti prozahodna smer s predsednico vlade Julijo Timošenko. Politično se je njena vlada naslonila na EU in z njo podpisala trgovinski sporazum. Z izvolitvijo Viktorja Janukoviča za predsednika države leta 2010 pa se je to spremenilo (povzeto po: The Economist, 2015). Ukrajinski parlament je junija 2010 izglasoval poseben zakon, s katerim se je Ukrajina zavezala, da ostaja zunaj kakršnega koli vojaškega zavezništva, dopuščal pa je stike z vojaškimi zavezništvi, kot je Nato.

Tako imenovana majdanska revolucija, ki se je končala z odstavitvijo predsednika Janukoviča in izvolitvijo nove vlade konec februarja 2014, je povzročila zavrnitev podpisa pridružitvenega sporazuma z EU novembra 2013. Rusija se je na imenovanje nove prozahodne vlade $\mathrm{v}$ Kijevu odzvala $\mathrm{z}$ intervencijo na polotoku Krim, ki si ga je marca 2014 po hitrem referendumu pripojila, na vzhodu Ukrajine (Doneck in Lugansk) pa je prišlo do upora rusko govorečega prebivalstva, vključno z razglasitvijo neodvisnosti teh dveh regij. To je sprožilo oborožen konflikt $\mathrm{z}$ vlado $\mathrm{v}$ Kijevu (povzeto po: The Economist, 2015).

Ukrajina je od razglasitve samostojnosti decembra 1991 lovila ravnotežje med Rusijo in Zahodom, a je bila do leta 2014 bolj ali manj v ruskem območju vpliva. Z odločitvijo, da se približa Zahodu, je praktično ogrozila ruske načrte o vzpostavitvi Evrazijske unije ${ }^{22}$, ki jo je Rusija načrtovala po vzoru EU (kot njeno protiutež), njena osrednja država bi bila Rusija, Ukrajina, na ozemlju katere je nekoč obstajala kijevska srednjeveška država, ki jo Rusi pojmujejo kot zibelko ruske državnosti, pa njen sestavni del. Kot trdi Neyfakh, si moderna ruska politična elita (pod Putinom in Medvedjevom) s projektom Evrazijske unije in njene vojaške različice (Organizacija Pogodbe o kolektivni varnosti) ${ }^{23}$ prizadeva povrniti geostrateški vpliv, ki ga je izgubila z razpadom Sovjetske zveze (povzeto po: Neyfakh, 2014).

\footnotetext{
${ }^{21}$ The Treaty on Conventional Armed Forces in Europe (The CFE Treaty). Pogodba iz leta 1990 je ena najpomembnejših pogodb o nadzoru oborožitve med hladno vojno. Členi pogodbe natančno določajo najvišje dovoljeno število kosov konvencionalnega orožja, ki je lahko med Atlantikom in Uralom. Pogodba je bila leta 1999 dopolnjena, predvsem z vidika konca hladne vojne in razpustitve Varšavskega pakta.

${ }^{22}$ Pogodba o ustanovitvi Evrazijske unije je začela veljati 1. januarja 2015. Namen te unije je gospodarsko in politično povezovanje držav, ki so nastale po razpustitvi Sovjetske zveze leta 1991. Po ruskih načrtih bi morala biti Ukrajina, poleg Belorusije in Kazahstana, četrta sopodpisnica ustanovitvene pogodbe.

${ }^{23}$ Organizacija je nastala leta 1992 iz držav naslednic Sovjetske zveze. Članice so Rusija, Kazahstan, Tadžikistan Kirgizistan, Belorusija in Armenija.
} 
Ni povsem jasno, kakšen je dolgoročni cilj priključitve Krima in kakšno ceno bo za ta korak plačala Rusija. Je pa z geostrateškega vidika polotok Krim pomemben

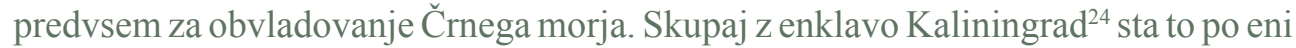
strani dva branika Rusije globoko v Evropi, po drugi pa dve točki, od koder je mogoče usmeriti silo proti Evropi in Natu. Kot navaja Adamowski, je Nato v najnovejši ruski vojaški doktrini ${ }^{25}$, ki je bila objavljena konec decembra 2014, opredeljen kot eden glavnih dejavnikov ogrožanja Rusije (povzeto po: Adamowski, 2015).

\subsection{Severna Afrika in Bližnji vzhod}

Varnost Evrope je bila od nekdaj odvisna tudi od njene neposredne južne in jugovzhodne soseščine. Od 19. stoletja naprej sta predvsem Francija in Velika Britanija obvladovali Severno Afriko, s propadom Otomanskega cesarstva po prvi svetovni vojni pa tudi Bližnji vzhod, ki sta si ga razdelili skladno s Sporazumom Sykes-Picot iz leta 1916 (The Sykes-Picot Agreement, 1916). V to obdobje segajo tudi vprašanje Palestine in ustanovitev Izraela ter razdelitev nadzora nad ozemljem Iraka in Sirije. Slednje sto let pozneje povzroči grožnje Evropi zaradi razglasitve Islamskega kalifata v Iraku in Siriji - ISIL ${ }^{26}$. Dejstvo je, da se je v zadnjih nekaj letih varnostna situacija poslabšala, predvsem pa po arabski pomladi, ki se je začela decembra 2010 v Tunisu, nadaljevala v Egiptu ter privedla do intervencije Nata v Libiji leta 2011 (Nato, 2014). Celotno območje je, predvsem zaradi nedelovanja državnih struktur, postalo varnostno izrazito nestabilno in dolgoročno nevarno za Evropo.

Sklep V minulih sto letih se je Evropa zelo spremenila. Dvajseto stoletje, ki se je politično gledano začelo s prvo svetovno vojno in končalo s terorističnimi napadi 11. septembra 2001 v ZDA, je popolnoma spremenilo geopolitični zemljevid Evrope in sveta. Tako druga svetovna vojna kot tudi hladna vojna sta obe logični posledici prve svetovne vojne, prav tako Društvo narodov, ki ga je Wilson videl kot temelj novega svetovnega reda, in katerega pravni naslednik je Organizacija združenih narodov.

Varnostno-politični izzivi, s katerimi se danes srečujemo, večinoma izvirajo iz odločitev in dogodkov, ki so se zgodili zaradi prve svetovne vojne oziroma njenih posledic. Do konca hladne vojne je bila večina teh konfliktov zamrznjena oziroma jih je nadzorovala ena ali druga velesila. Po koncu hladne vojne pa je prišel čas preurejanja, predvsem v Evropi je prišlo s padcem Berlinskega zidu do največjih geostrateških sprememb, med njimi do združitve Nemčij ter razpada Sovjetske zveze, Jugoslavije in Češkoslovaške. Ti dogodki so v dveh desetletjih povzročili popolnoma drugačno geostrateško sliko v Srednji in Vzhodni Evropi.

\footnotetext{
${ }^{24}$ Kaliningrad je ruska enklava ob Baltskem morju, kjer je sedež ruske baltske flote.

${ }_{25}$ V novi doktrini, ki jo je ruski predsednik Putin podpisal 26. decembra 2014, najdemo odgovor Rusije na sklepe Nata, sprejete na vrhu v Walesu septembra 2014. Šrjenje Natove infrastrukture k ruskim mejam je ena največjih groženj. Kot odgovor na to nova doktrina predvideva tesnejše sodelovanje z državami BRICS (Brazilija, Indija, Kitajska in Južna Afrika). Nova doktrina predvideva tudi povečanje ruske vojaške prisotnosti na območju Arktike in razvoj raketne obrambe, skupaj z ruskimi zaveznicami.

${ }^{26}$ Islamska država v Iraku in Levantu (angl. Islamic State in Iraq and Levant - ISIL).
} 
Današnja združena Nemčija, ki je tudi naslednica nekdanje zahodne Nemčije, je drugačna od tiste izpred leta 1989. Je bolj samozavestna, gospodarsko uspešna, vendar vojaško in geostrateško ostaja previdna in sistematična. Današnja Nemčija je z združitvijo podedovala geostrateške elemente obeh Nemčij, vključno z bremeni prve in druge svetovne vojne. Ob upoštevanju teh dejavnikov je lažje razumeti današnjo nemško strateško postavljanje v središče Evrope, kot most med nekdanjo Zahodno in Vzhodno Evropo, ki vključuje Rusijo in Rumsfeldovo novo Evropo, kar po Mackinderju sovpada z zahodnim delom strateškega osrčja. Izkušnje dveh vojn in obdobja do leta 1990 se logično kažejo v nemški zunanji in obrambni politiki (povzeto po: Kurbjuweit, 2014). Po eni strani (predvsem od napada ZDA na Irak leta 2003) deluje bolj suvereno, po drugi pa si prizadeva za zbližanje gospodarskih in političnih odnosov z Rusijo, na podlagi izkušenj iz obeh svetovnih vojn pa svari pred eskalacijo konfliktov.

Evropskimir, utemeljen naizkušnjah prvein druge svetovnevojne terinstitucionaliziran z Evropsko unijo, temelji predvsem na miru in prijateljstvu med Francijo in Nemčijo. Seveda pa je pri tem treba upoštevati predpostavko, da državi sprejemata ta odnos na enakopravnih temeljih, pri čemer se lahko ta občutek spremeni (povzeto po: Smale, Alderman, 2014), če pride do gospodarske prevlade ene države. Desetletja po drugi svetovni vojni ta mir ni bil ogrožen. Trenutne razmere kažejo na šibkejšo gospodarsko moč Francije in prevladujoč položaj Nemčije, ki se kaže v povečanem političnem vplivu. To je posebno opazno v vzhodnem delu Evropske unije oziroma tako imenovani novi Evropi, v kateri ima Nemčija močan politični vpliv.

Zgodovinsko je takšna pozicija lahko varnostno vprašljiva, saj lahko zrahlja odnose s Francijo in tudi z Veliko Britanijo, ki je na kontinentu tradicionalno poskušala preprečevati prevlado katere koli evropske sile. S podpisom Strateškega sporazuma leta 2010 so se težnje približevanja Francije in Velike Britanije začele jasneje nakazovati. Rahljanje ustaljenega ravnotežja v Evropi, katerega povod (in ne razlog) je finančna kriza leta 2008, se v Veliki Britaniji kaže tudi v zavezi britanskega premierja Camerona, da leta 2017 razpiše referendum o prihodnosti Velike Britanije v Evropski uniji, kar je lahko nevaren precedens za prihodnost Evropske unije.

$\mathrm{Na}$ drugi strani je Rusija, ki hote ali nehote spominja na poversajsko Nemčijo. Zanimivo je, da vladajoče ruske politične elite vidijo Rusijo kot naslednico Sovjetske zveze ne le v pravnem, temveč tudi v političnem in teritorialnem smislu. Neodvisne države, ki so nastale na ozemlju nekdanje Sovjetske zveze, vidijo kot izgubljeno ozemlje (podobno kot je to počela weimarska Nemčija, ki je ozemlje izgubila po letu 1918). Podobnosti v politični anarhiji devetdesetih let v Rusiji in dvajsetih v Nemčiji, v gospodarski krizi v Rusiji leta 1998 ter v Nemčiji takoj po vojni ter predvsem v občutku ponižanja zaradi kapitulacije v prvi svetovni vojni oziroma izgube v hladni vojni se ponujajo same od sebe. $Z$ dogodki, ki smo jim bili priča leta 2014, ter ob dejstvu, da se je Rusija umaknila iz Pogodbe o konvencionalnih silah ter da prav tako ne izpolnjuje obveznosti iz Pogodbe o jedrskih silah srednjega dometa, pomeni, da se geostrateško odmika od preostale Evrope. 
Zanimiva je drža ZDA, ki so januarja 2012 z razglasitvijo novih strateških usmeritev svojo vojaškopolitično pozornost namenile vzhodni Aziji in Pacifiku. S tem so prvič po prvi svetovni vojni svojo primarno strateško pozornost uradno prenesle iz Evrope.

Kitajska, ki je v tem članku nismo podrobneje omenjali, ostaja neznanka. Kljub temu je jasno, da Peking postaja vedno pomembnejši sogovornik Washingtona o globalnih zadevah. Značilen je primer ukrajinske krize, v kateri je bila od stalnih članic Varnostnega sveta Združenih narodov Kitajska edina, ki ni bila neposredno vpletena, kar ji daje manevrski prostor, da, kot pravi avtor, »stopi v čevlje, ki jih je nekdaj nosila Sovjetska zveza«. Kitajska je po začetku ukrajinske krize z Rusijo podpisala sporazum o gradnji plinovoda, s čimer jo je v perspektivi tesneje vezala nase, Rusiji pa omogočila alternativno tržišče ${ }^{27}$. Kot protiutež sankcijam, ki jih je uvedla Evropska unija, ji je, kot piše Rettman, ob koncu leta 2014 ponudila tudi denarno pomoč (Rettman, 2014). Nastaja vtis in o tem piše tudi Zanitti, da se s približevanjem Kitajske in Rusije (ter pogojno tudi Indije) nakazujejo poskusi vzpostavitve novega, večpolarnega sveta (povzeto po: Zanitti, 2015). Ta korak lahko razumemo tudi kot logičen odgovor Pekinga (in Moskve) na preusmeritev ZDA v vzhodno Azijo in na Pacifik.

Kot vidimo pri samooklicani Islamski državi v Levantu(ISIL), pa prazen prostor, ki nastane za propadlimi državami, odpira vrata novim igralcem. Trenutno je težko napovedati, kakšna je prihodnost Bližnjega vzhoda, dejstvo pa je, da dejavniki, kot je ISIL, skupaj s terorističnimi organizacijami, ki so povezane z Al-Kaido, rušijo sedanji red na Bližnjem vzhodu. Dodatno skrb povzročajo tudi njihove aktivnosti v Evropi, kar ima neposreden vpliv na notranjo politiko evropskih držav ${ }^{28}$ in njihovo razumevanje varnosti.

V teh letih, ko se svet spominja stote obletnice začetka prve svetovne vojne, je položaj v Evropi in svetu vse prej kot preprost. Kriza v Ukrajini je svet privedla do največjih napetosti med Rusijo in ZDA (s članicami Nata) po koncu hladne vojne. Ta kriza je razgalila vso krhkost sedanjega svetovnega reda. Trenutno je najšibkejša točka Evrope Rumsfeldova nova Evropa kot del Mackinderjevega osrčja, ki je bila ob vseh velikih svetovnih spremembah predmet geostrateških preigravanj in, kot temu pravi avtor, »lakmusov papir« prihodnjih dogodkov.

V tem trenutku je težko reči, ali smo pred tako velikimi spremembami, da bo v svetu nastal nov red, pojavljajo pa se težnje, ki spominjajo na tiste izpred prve svetovne vojne, predvsem podobnosti v vedenju držav in neformalnem obujanju tradicionalnih zavezništev. Občutiti in opaziti je mogoče veliko dejavnikov, ki so bili našteti v tem članku, ki nakazujejo, da bo obdobje, ki prihaja, drugačno od tistega, ki smo ga živeli do zdaj. Čas bo pokazal, ali smo pridobljene izkušnje iz zadnjih sto let uporabili tako, da smo se v prelomnih trenutkih sposobni izogniti napakam, ki so bile narejene $\mathrm{v}$ stoletju, ki je za nami.

\footnotetext{
${ }^{27}$ Po podatkih Thomas White International je industrija, povezana z nafto in plinom, leta 2010 predstavljala $30 \%$ ruskega BDP in $60 \%$ vsega ruskega izvoza.

${ }_{28}$ Teroristični napadi po Evropi prispevajo $k$ vzponu antiislamističnih strank, kar radikalizira notranjepolitične razmere v evropskih državah.
} 


\section{Literatura}

1. Adamowski, J., 2015. Russia Overhauls Military Doctrine. Defence News International, Vol. 3 No. 1, Gannett Government Media, Springfield, VA, 2015.

2. Baker, M., 2003. U. S.: Rumsfeld's 'Old'And 'New'Europe Touches On Uneasy Divide, Radio Free Europe, http://www.rferl.org/content/article/1102012.html, 15. januar 2015.

3. BBC News, 2007. Russia suspends arms control pact. BBC, http://news.bbc.co.uk/2/hi/ europe/6898690.stm, 15. januar 2015.

4. Encyclopedia Britannica, 2014. European History, Franco-German War, http://www. britannica.com/EBchecked/topic/216971/Franco-German-War, 12. januar 2015.

5. Encyclopedia Britannica, 2013. Sir Halford John Mackinder. http://www.britannica.com/ EBchecked/topic/354948/Sir-Halford-John-Mackinder, 14. januar 2015.

6. European Union, 2014. EU treaties, http://europa.eu/eu-law/decision-making/treaties/ index en.htm, 20. december 2014.

7. Ferguson, S. T., 2014. Game Theory, Mathematics department, UCLA, http://www.math. ucla.edu/ tom/Game_Theory/mat.pdf, 10. januar 2015.

8. Friedman, G., 2014. Geopolitical Journey, Part 2: Borderlands, Stratfor, http://www.stratfor.com/weekly/20101108_geopolitical_journey_part_2_ borderlands\#axzz3PqhmmCx3, 3. junij 2014.

9. Friedman, G., 2014. The Top Five Events in 2014, Stratfor, http://www.stratfor.com/ weekly/top-five-events-2014\#axzz3OssDl2Ds, 7. januar 2015.

10. Gherghisan, M., 2003. Vilnius 10 sign letter on Iraq, EU Observer, https://euobserver. com/enlargement/9269, 16. december 2014.

11. Kurbjuweit, D., 2014. The Merkel Effect: What Today's Germany Owes to Its OnceCommunist East, Spiegel Online International, http://www.spiegel.de/international/ germany/how-east-germany-influences-modern-day-german-politics-a-994410.html, 8 . oktober 2014.

12. Mackinder, H. J., 1919. Democratic Ideals and Reality: A Study in the Politics of Reconstruction, National Defence University, Institute for National Strategic Studies, National University Press Publications, Washington D.C.,1942.

13. Mackinder, H. J., 1904. The Geographical Pivot of History. The geographical Journal, Vol. 23, No. 4, 421-431, The Royal Geographical Society, London, 2004.

14. MacMillen, M., 2003. Paris 1919, Six months that changed the world. The Random House Publishing Group, New York, 2003.

15. National Centre for Strategic Studies, 2014. America needs a Poland that is more self sufficient, Stratfor, http://www.stratfor.com/the-hub/america-needs-poland-more-selfsufficient\#axzz3679aDxI5, 1. julij 2014.

16. Neyfakh, L., 2014. Putin's long game? Meet the Eurasian Union, The Boston Globe, http://www.bostonglobe.com/ideas/2014/03/09/putin-long-game-meet-eurasianunion/1eKLXEC3TJfzqK54elX5fL/story.html, 20. december 2014.

17. NATO, 2014. A short history of NATO, http://www.nato.int/history/index.html, 15. december 2014.

18. NATO, 2009. Article 51 of the Charter of the United Nations, NATO, http://www.nato.int/ cps/en/natolive/official_texts_16937.htm, 17. september 2014.

19. NATO, 2014. ISAF, NATO, http://www.isaf.nato.int/, 1. oktober 2014.

20. NATO, 2014. NATO-Russia Council, NATO, http://www.nato.int/cps/ro/natohq/ topics_50091.htm, NATO Russia Council, 29. december 2014.

21. NATO, 2014. Statement by the Secretary General on the INF Treaty, NATO, http://www. nato.int/cps/en/natolive/news_111823.htm, 29. december 2014.

22. NATO, 2008. Bucharest Summit Declaration, NATO, http://www.nato.int/cps/en/natohq/ official_texts_8443.htm?selectedLocale=en, 29.december 2014.

23. NATO, 1949. The North Atlantic Treaty, http://www.nato.int/cps/en/natolive/official_ texts_17120.htm, 20. december 2014. 
24. Nelson, M.R., Belkin, P., Mix, D.E., 2011. Greece's Debt Crisis: Overview, Policy. Responses, and Implications, Congressional Research Service, http://fas.org/sgp/crs/row/ R41167.pdf, 10. oktober 2014.

25. OSCE, 2013. Conference on Security and Co-Operation in Europe Final Act 1975, http:// www.osce.org $/ \mathrm{mc} / 39501$ ? download=true, 30. september 2014.

26. OSCE, 2007. OSCE Chairman expresses hope for renewed CFE negotiations, http://www. osce.org/cio/49292, 6. december 2014.

27. Rettman, A., 2014. China ignores EU, offers to help Russia, EU Observer, https:// euobserver.com/foreign/127036. 14, in 15. januar 2015.

28. Simms, B., 2013. Europe: The Struggle for Supremacy, from 1453 to the Present, Basic Books, New York, 2013.

29. Smale, A., and Alderman, L., 2014. Growing Imbalance between Germany and France strains their relationship, The International New York Times, http://www.nytimes. com/2014/09/22/world/europe/imbalance-between-germany-and-france-strainsrelationship.html? $r=0$, 13. januar 2015.

30. The Charter of the United Nations, 1945, http://avalon.law.yale.edu/20th_century/ unchart.asp, 1. januar 2015

31. The Covenant of the League of Nations, 1919. http://avalon.law.yale.edu/imt/parti.asp, 1. januar 2015.

32. The Economist, 2013. The origins of the financial crisis, Crash course, The Economist, http://www.economist.com/news/schoolsbrief/21584534-effects-financial-crisis-are-stillbeing-felt-five-years-article, 9. oktober 2014.

33. The Economist, 2013. The road to 2017. What the reshuffle says about David Cameron's plans for Europe, http://www.economist.com/news/britain/21607833-what-reshuffle-saysabout-david-camerons-plans-europe-road-2017, 17. december 2014.

34. The Economist, 2014. Europe's elections. The Eurosceptic Union. The impact of the rise of anti-establishment parties, in Europe and abroad, The Economist, http://www. economist.com/news/europe/21603034-impact-rise-anti-establishment-parties-europeand-abroad-eurosceptic-union, 14 januar 2015.

35. The Economist, 2015. From cold war to hot war, Russia's aggression in Ukraine is part of a broader, and more dangerous, confrontation with the West, http://www.economist.com/ news/briefing/21643220-russias-aggression-ukraine-part-broader-and-more-dangerousconfrontation, 14. februar 2015.

36. The Guardian, 2003. France and Germany unite against Iraq war, The Guardian, http:// www.theguardian.com/world/2003/jan/22/germany.france, 01. oktober 2014.

37. The Military Doctrine of the Russian Federation, 2010. http://www.sras.org/military_ doctrine_russian_federation_2010,29. december 2014.

38. The Monroe doctrine, 1823. http://web.archive.org/web/20120108131055/http:/eca.state. gov/education/engteaching/pubs/AmLnC/br50.htm, 10. januar 2015.

39. The Sykes-Picot Agreement, From WW I Document Archive, 1916. http://www.saylor.org/ site/wp-content/uploads/2011/08/HIST351-9.2.4-Sykes-Picot-Agreement.pdf, 12. januar 2015.

40. The Three-Power Pact between Germany, Italy, and Japan, 1940. http://avalon.law.yale. edu/wwii/triparti.asp, 1. januar 2015.

41. The Treaty on Elimination of Intermediate-Range and Shorter-Range Missiles- between USA and USSR (The INF Treaty text 1987), http://cns.miis.edu/inventory/pdfs/aptinf.pdf, 29. december 2014.

42. The Japan Times, 2014. Russian military regain its clout, http://www.japantimes.co.jp/ news/2014/02/28/world/russian-military-regains-its-clout/\#.VMPUakfF_ht, 1. januar 2015 . 
43. Thomas White International, 2011. Oil \& Natural Gas Sector in Russia: Fueling Growth, http://www.thomaswhite.com/global-perspectives/oil-natural-gas-sector-in-russia-fuelinggrowth/, 10. januar 2015.

44. Trading Economics, 2015. Russia GDP 1989 - 2015, http://www.tradingeconomics.com/ russia/gdp, 2. januar 2015.

45. UK, 2010. The Treaty between the United Kingdom of Great Britain and Northern Ireland and the French Republic for Defence and Security Co-operation, https://www.gov.uk/ government/uploads/system/uploads/attachment_data/file/238153/8174.pdf, 14. januar 2015.

46. UN, 2014. Structure and organization of the United Nations, UN, http://www.un.org/en/ aboutun/structure/\#Others, 17. september 2014.

47. UN, 2002. United Nations Security Council Resolution 1441 (2002), http://www.un.org/ depts/unmovic/documents/1441.pdf, 1. oktober 2014.

48. U.S. Department of Defence, 2012. Sustaining US Global Leadership: Priorities for 21st Century Defence, US Department of Defence, http://www.defense.gov/news/defense strategic_guidance.pdf, 3. julij 2014.

49. U.S. Department of State, 2014. Adherence to and Compliance with Arms Control, Nonproliferation, and Disarmament Agreements and Commitments, http://www.state.gov/ documents/organization/230108.pdf, 30. september 2014.

50. Wilson, W., 2015. The Biography.com website, http://www.biography.com/people/ woodrow-wilson-9534272, 14. januar 2015.

51. Zanitti, B. F., 2015. Russia, China and India building new multipolar world order, http:// english.pravda.ru/world/asia/15-01-2015/129526-russia_china_india-0/, 15. januar 2015. 